In the almost twenty years between the two international conferences on John Wyclif organised by the University of Milan, the most recent of which (September 2016) lies to some extent at the origin of the present volume, an increasing number of studies have been devoted to this great English thinker, theologian and reformer. These have enhanced our knowledge of his philosophical, theological and pastoral work, which had long remained in the shadows. The essays collected in the present book take further steps along this path, through the contribution of a range of specialists who have been called to further reconstruct Wyclif's place in his intellectual milieu from the standpoint of his textual and doctrinal dependence and influence: the collected essays deal with the antecedents of Wyclif's thought, his sources, and his role as a source for countless followers and opponents.

The following authors have contributed to the volume Graziana Ciola, Alessandro D. Conti, Kantik Ghosh, Stephen E. Lahey, Ian Christopher Levy, Jindřich Marek, Sean Otto, Aurélien Robert and Mark Thakkar.

Luigi Campi and Stefano Simonetta both teach History of Medieval Philosophy at the Università degli Studi di Milano. They have devoted an extensive series of papers and essays to John Wyclif, across fields ranging from political theology and ecclesiology to soteriology, metaphysics and Wyclif's reception in Bohemia; L. Campi has published a critical edition of De scientia Dei (Oxford 2017), while S. Simonetta is the author of Si salvi chi può? Volere divino, merito e dominio nella riflessione del primo Wyclif(Bergamo 2007).

Cover: Commentary on Aristotle's Physics (Venezia, Biblioteca Nazionale Marciana, Lat. VI. 173, f. 58v). (C) Ministero dei Beni e delle Attività Culturali e del Turismo and Biblioteca Nazionale Marciana.
Fédération Internationale des Instituts d'Études Médiévales

TEXTES

ET

ÉTUDES

DU

MOYEN

ÂGE,

97

BEFORE AND AFTER WYCLIF: SOURCES AND TEXTUAL INFLUENCES

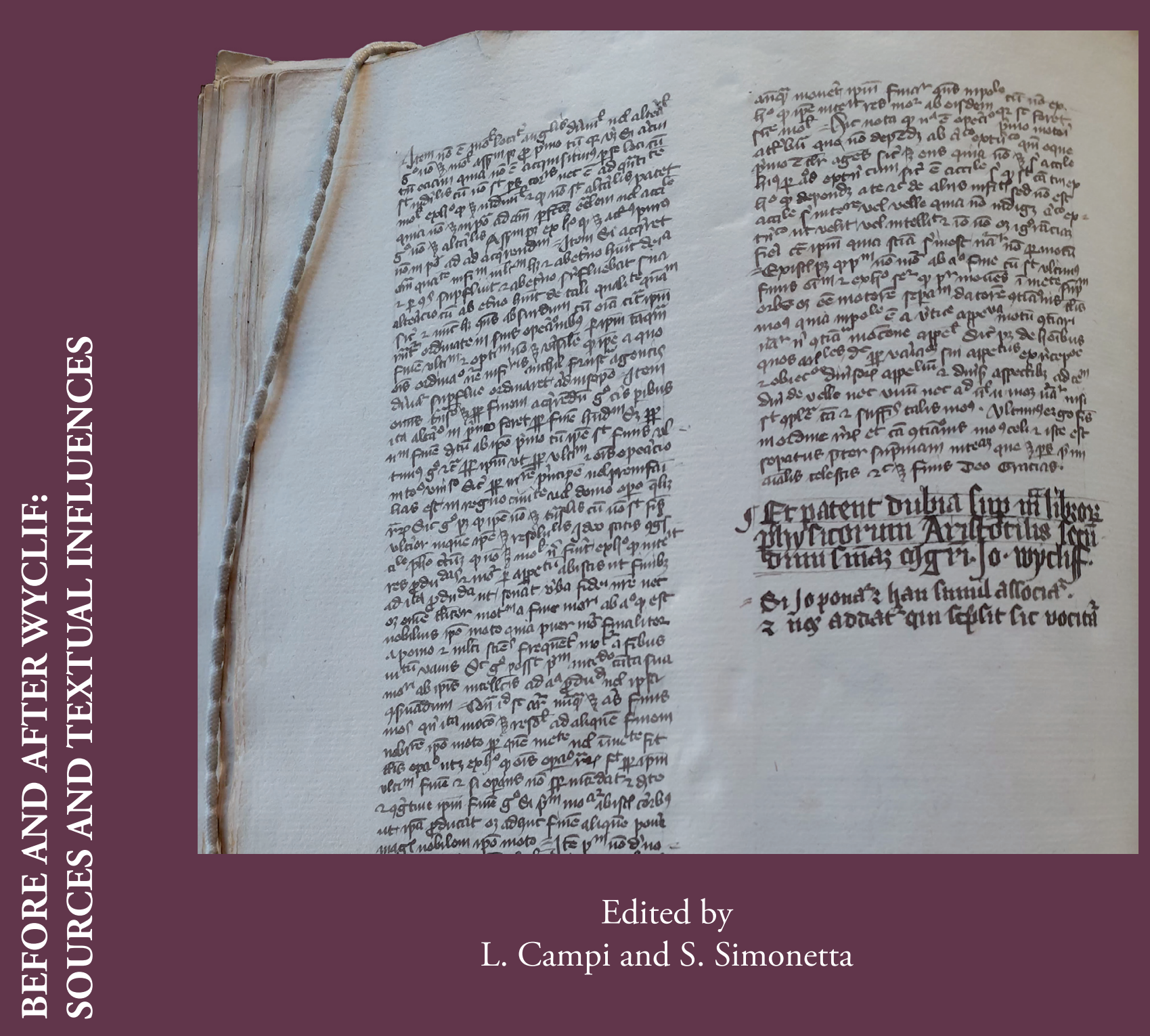


Fédération Internationale des Instituts d'Études Médiévales TEXTES ET ÉTUDES DU MOYEN ÂGE, 97

\section{BEFORE AND AFTER WYCLIF:} SOURCES AND TEXTUAL INFLUENCES

Edited by

L. CAMPI and S. SimonetTA 


\section{$f \mathbb{D Q M}$}

FÉdÉration Internationale des Instituts d’Études Médiévales

Présidents honoraires:

Leonard E. Boyle $(\dagger)$ (Biblioteca Apostolica Vaticana et Commissio Leonina)

Louis Holtz (Institut de Recherche et d'Histoire des Textes, CNRS, Paris) Jacqueline HAMEsSE (Université Catholique de Louvain, Louvain-laNeuve)

Président :

Maarten J. F. M. HoEnen (Universität Basel)

Vice-Président et Éditeur responsable :

Ana Gómez Rabal (Institución Milá y Fontanals, CSIC, Barcelona)

Secrétaire :

Marta Pavón Ramírez (Centro Español de Estudios Histórico-Eclesiásticos, Roma)

Trésorier :

Ueli ZaHND (Université de Genève)

Membres du Comité:

Alexander Baumgarten (Universitatea Babeş-Bolyai, Cluj-Napoca)

Patricia CañIzares Ferriz (Universidad Complutense de Madrid)

Massimiliano Lenzi (Sapienza, Università di Roma)

Roberto H. Pich (Pontificia Universidade Católica do Río Grande do Sul, Porto Alegre)

Dominique PoIrel (Institut de Recherche et d'Histoire des Textes, CNRS, Paris)

Anne-Marie Turcan-Verkerk (École Pratique des Hautes Études, PSL, Paris)

Carmela ViRCillo-Franklin (Columbia University, New York) 
Fédération Internationale des Instituts d'Études Médiévales TEXTES ET ÉTUDES DU MOYEN ÂGE, 97

\section{BEFORE AND AFTER WYCLIF: SOURCES AND TEXTUAL INFLUENCES}

Edited by

L. CAmpI and S. SimonetTA

Basel

2020 
Cover illustration: By permission of the Italian Ministry of Cultural Heritage and Activities and of Tourism - Marciana National Library (Biblioteca Nazionale Marciana, Venice). Prohibition of reproduction.

ISBN: 978-2-503-59406-4

E-ISBN: 978-2-503-59407-1

DOI: 10.1484/M.TEMA-EB.5.122974

All rights reserved. No part of this publication may be reproduced, stored in a retrieval system or transmitted, in any form or by any means, electronic, mechanical, photocopying, recording or otherwise, without the prior permission of the publisher.

(C) 2020 Fédération Internationale des Instituts d'Études Médiévales.

Philosophisches Seminar

Universität Basel

Steinengraben 5

CH-4051 Basel (Schweiz) 


\section{CONTENTS LIST}

Luigi CAMPI - Stefano SimonetTa, Introduction VII

Mark ThakKar, Wyclif's Logica and the Logica Oxoniensis

Alessandro D. ConTI, Oxford Realists' Criticism of Walter Burley's

Last Theory of Proposition

Aurélien RoberT, Atomism at Oxford after John Wyclif. The Cases of Robert Alyngton and Roger Whelpdale

Stephen E. LAHEy, Stanislaus of Znojmo and the Ecclesiological Implications of Wyclif's Divine Ideas

Ian Christopher Levy, The Words of Institution and Devotion to the Host in the Wake of Wyclif

Sean Отто, Anti-fraternalism and the Sources of John Wyclif's Sermones

Kantik GHosh, After Wyclif: Philosophy, Polemics and Translation in The English Wycliffite Sermons

Jindřich MAREK, Jakoubek of Stř́bro as a Wycliffite. The Testimony of His Sermon Collections

Graziana Ciola, The Apologue of the Birds

Bibliography

Index of Names

Ancient and Medieval Authors

Modern and Contemporary Authors

Index of Manuscripts 
KANTIK GHOSH*

\section{AFTER WYCLIF: PHILOSOPHY, POLEMICS AND TRANSLATION IN THE ENGLISH WYCLIFFITE SERMONS}

John Wyclif produced a substantial set of ca. 183 sermons after his enforced retirement from Oxford in $1382^{1}$. These are complex and idiosyncratic texts and foreground a characteristic feature of much of his later output: a tendency to superimpose simultaneously a multiplicity of generic and conceptual frameworks onto exegesis. What is apparently meant to be homiletic scriptural exposition is therefore overlaid by discourses and methods relating to metaphysics, epistemology, Sprachlogik and topical polemics. Intra-clerical philosophical speculation and extra-clerical instruction of the "people'2 merge pervasively into each other, and the resultant, highly malleable, discursive form implicitly denies the necessity of tailoring language, style and method to one's particular materia subiecta or one's audience ${ }^{3}$. A recent commentator memorably describes Wyclif's hermeneutic treatise De veritate sacre scripture

* Associate Professor of English and Stirling-Boyd Fellow and Tutor, Trinity College, University of Oxford, UK. kantik.ghosh@trinity.ox.ac.uk

${ }^{1}$ Wyclif's complete sermons, including a set dating from his university-years, are edited as John Wyclif, Sermones, Ed. by J. Loserth, 4 vols., Trübner \& Co., London 1887-1890. All references are to this edition (henceforth Sermones) and supplied in the footnotes by volume, page and line number.

${ }^{2}$ For Wyclif's references to a postulated lay audience, see A. Hudson, «Wyclif’s Latin Sermons: Questions of form, date and audience», in EAD., Studies in the Transmission of Wyclif's Writings, Ashgate Variorum, Aldershot 2008, VI, pp. 223248: 233.

${ }^{3}$ The comments here summarize my conclusions in «Genre and Method in the Late Sermones of John Wyclif», in U.ZAHND (ed.), Language and Method: Historical and Historiographical Reflections on Medieval Thought, Rombach, Freiburg-imBreisgau 2017, pp. 167-182. The seminal article on the question of method, style and materia subiecta is by Z. KALUZA, «Les sciences et leurs langages: note sur le statut du 29 décembre 1340 et le prétendu statut perdu contre Ockham», in L. Bianchi (ed.), Filosofia e teologia nel Trecento: Studi in ricordo di Eugenio Randi, FIDEM, Louvainla-Neuve 1994, pp. 197-258. 
as 'un traité-fleuve"'; the appellation could be extended to much of his other output, including the sermons. The intellectual density and allusive complexity of these pieces, as well as their methodological indeterminacy and slipperiness, form a rich -and for contemporaries, both pro and contra, highly problematic- discursive nexus: a problem intensified by Wyclif's propensity to introduce and discuss philosophical dubia at length while ostensibly focusing, as for example in the Sunday Gospel sermons, on the preaching of pastoralia.

When Wyclif's followers came to produce a vast corpus of learned and quasi-learned materials, in English as well as in Latin, in the rough period of half a century from 1370-1420, they appear to have come up, on the evidence of some of the most substantial, and widely disseminated, surviving Lollard texts, with a two-pronged approach. A significant portion of what one might describe as scholarly aids to the study of the Bible, primarily in English, does draw upon Wyclif's radical ideas in part but chooses a largely conventional, academically rigorous method and style. These works include such major productions as the Bible translation (including translations of the standard Jerome prefaces accompanying the Paris Bible) $)^{5}$, the translation of patristic scholarship known as the Glossed Gospels drawing upon the catena aurea and various other authoritative sources ${ }^{6}$, and the set of distinctiones which make up the Floretum / Rosarium in Latin (with one extant English translation $)^{7}$. The aim of these productions is to equip the reader of the biblical text (presumably in English) with a largely uncontroversial and unexceptionable set of scholarly tools; together, they constitute nothing less than the 'translation' of a whole academic method and mentalité into the vernacular. Ideologically inflected polemics as also speculative theology take a back-seat here, though they occasionally do intrude.

${ }^{4} \mathrm{~F}$. GOUBIER, «Les propriétés du discours sont-elles réductibles à celles des mots? Sémantique de l'impropre chez John Wyclif et John Kenningham», Beiträge zur Geschichte der Sprachwissenschaft, 23 (2013) 173-198: 174.

${ }^{5}$ See, most recently, the papers collected in E. Solopova (ed.), The Wycliffite Bible: Origin, History, and Interpretation, Brill, Leiden 2016.

${ }^{6}$ The authoritative account is A. Hudson, Doctors in English: A Study of the Wycliffite Gospel Commentaries, Liverpool University Press, Liverpool 2015.

${ }^{7}$ These remain unedited; there is a partial edition of the English version in C. von Nolcken (ed.), The Middle English Translation of the Rosarium Theologie: a selection, Carl Winter, Heidelberg 1979. 
The genres are recognizable in terms of the standard scholastic models of exegesis and commentary, distinctiones and catenae; the methods, relating to often highly labour-intensive textual criticism and a sustained engagement with biblical correctoria and with patristic originalia, can be of astonishingly high academic rigour ${ }^{8}$.

However, the English followers of Wyclif also produced a quite different body of texts: these would include the original Wycliffite prologues accompanying the Wycliffite Bible in a range of copies, of which the so-called General Prologue is the most famous example ${ }^{9}$; stand-alone polemical tracts such as the one on the Eucharist edited by Anne Hudson ${ }^{10}$, and most significantly, the long (and widely disseminated) cycle of 294 sermons in English known as the English Wycliffite Sermons ${ }^{11}$. These works are much more stridently and sustainedly polemical, and methodologically, they come close to replicating the later Wyclif. Generically and in terms of style, they form a characteristic new vernacular Wycliffite category, one that combines, in a fluid and malleable fashion, aspects of philosophical theology, of Sprachlogik and grammatical analysis, of moral and spiritual exegesis and of homiletic exhortation -all of which can without warning merge into virulent anticlerical and anti-sacramental polemics ${ }^{12}$. In particular, the English Wycliffite Sermons, which will form the focus of

${ }^{8}$ See A. Hudson - E. Solopova, «The Latin Text», in Solopova (ed.), Wycliffite Bible, op. cit., pp. 107-132; Hudson, Doctors in English, pp. liii-xcv.

${ }^{9}$ See my discussion in «The Prologues», in Solopova (ed.), Wycliffite Bible, op. cit., pp. 162-182.

${ }^{10}$ See A. Hudson (ed.), The Works of a Lollard Preacher. The Sermon Omnis plantacio, The tract Fundamentum aliud nemo potest ponere, and The tract De Oblacione iugis sacrificii, Oxford University Press, Oxford 2001; see my discussion in «Wycliffite 'Affiliations' - Some Intellectual-Historical Perspectives», in M. Bose J.P. Hornbeck II (eds.), Wycliffite Controversies, Brepols, Turnhout 2011, pp. 13-32.

${ }^{11}$ English Wycliffite Sermons, Ed. by A. Hudson - P. Gradon, 5 vols., Clarendon Press, Oxford 1983-1996. All references, unless specified otherwise, are to this edition (henceforth $E W S$ ) and supplied in the footnotes by volume, page and line number. For details of the many surviving manuscript copies and derivatives, see EWS, vol. 1, pp. 51-123.

${ }^{12}$ It is not of course my intention to suggest that the two broad categories outlined here constitute an adequate taxonomy of the astonishingly varied Wycliffite textual output; however, a large number of major texts can, for the purposes of analysis, be productively aligned along these lines. For the range and diversity of Wycliffite scholarship and textual productions, see A. Hudson, The Premature Reformation: Wycliffite Texts and Lollard History, Clarendon Press, Oxford 1988, chapters 4-5, pp. 174-277. 
this paper, draw extensively, though irregularly and diffusely, on Wyclif's own sermons ${ }^{13}$, and it is instructive to examine how they respond to their peculiar texture. Of especial note is the Sunday Gospel set, in which, as Hudson has pointed out, Wyclif appears to be peculiarly aware of the teaching needs of the parish priest and the traditional association of such sermons with the preaching of pastoralia ${ }^{14}$. We will begin with looking at a selection of key passages from these sermons and their rendition into the vernacular.

Wyclif's $11^{\text {th }}$ sermon on the Sunday Gospels has John 2 -the marriage at Cana- as pericope, and EWS Sermon 33 on the Sunday Gospels on the same theme draws extensively on it. Wyclif begins by speculating on the identity of the bridegroom:

[...] creditur a magis probabili quod iste nupcie erant beati Johannis Evangeliste cum muliere nobis incognita (quam quidam fingunt fuisse Magdalene) desponsati, et sic die tercia a vocacione Philippi et Nathaneel (de qua Johannis $1^{\circ}$ ) in oppido Galilee quod Chana dicitur hoc miraculum supponitur probabiliter esse factum ${ }^{15}$.

The English sermon gives the following rendition:

[...] as men seyn comunly, Iohn the Euangelist was weddid here [...] Studye we not to what woman Iohn was weddid, ne axe we not auctorite to proue pat Iohn was weddid now, for pat pat the gospel seip here is ynow to cristene feip ${ }^{16}$.

The vernacular sermon makes some attempt at simplifying Wyclif's Latin: his terminology of probabilism ${ }^{17}$ is here replaced by a somewhat apologetic dismissal of the issue of whether or not the wedding at Cana was that of John. The phrase exhorting us not to 'study' suggests that

${ }^{13}$ See P. Gradon, «Relation of the English Cycle to Wyclif's Latin sermons», in $E W S$, vol. 3, pp. xcix-cxlviii; also the detailed editorial notes in EWS, vols. 4 and 5.

${ }^{14}$ Hudson, «Wyclif's Latin sermons», p. 234.

${ }^{15}$ Sermones, vol. 1, serm. 11, p. 72/26-32.

${ }^{16}$ EWS, vol. 1, p. 360/4-9.

${ }^{17}$ On probabilistic terminology in Wycliffite discourse, see my «And so it is licly to men: Probabilism and Hermeneutics in Wycliffite Discourse», The Review of English Studies, n.s. 70 (2019), 418-436. 
such questions amount to unhealthy $\operatorname{curiositas}^{18}$, a critique related to that abiding Wycliffite bête noire -the name of Tobit's dog ${ }^{19}$.

EWS 33 then omits two of Wyclif's mini-digressions: Christ's presence at Cana proves the legitimacy of marriage; furthermore, John was called to the apostolic vocation before consummation (on the authority of Jerome), and therefore either part of a married couple may enter religion or the priesthood before carnal consummation, provided there are no other obstacles ${ }^{20}$. Wyclif then embarks on a detailed grammatical / logicolinguistic analysis of Mary's verbal exchange with Jesus: Mary speaks «facete [courteously] et modeste [...] per modum interrogacionis», «they have no wine» (John 2:3), and it is evident to logicians and theologians that she could not have been guilty of lying («patet tam logicis quam theologis quod non oportet ipsam commisisse mendacium») $)^{21}$. Jesus's response in John 2:4 («Woman, what is that to me and to thee? My hour is not yet come») is formulated 'extranee' ('strangely' i.e. coldly / distantly) to indicate that the miracle would arise from his divine and not human nature. His response therefore is not merely strange but is phrased «instructive et racione preponderante» («in an instructive fashion and with the greater weight of reason») as this was going to be his first publicly performed miracle. Mary's desire for the miracle is willed only «modeste et condicionaliter» («modestly and conditionally»). Jesus's response is such that Mary understands her petition «non...repulsam sed racionabiliter dilatam» («not rejected but reasonably postponed») as through her perfect faith she knew Jesus to be omnipotent, omniscient

${ }^{18}$ On the various connotations of 'study' in Middle English, see N. ZeEman, «"Studying" in the Middle Ages - and in Piers Plowman», New Medieval Literatures, 3 (1999) 185-212.

${ }^{19}$ Speculating on the identity of Tobit's dog (cf. Tobias 6:1, 11:9) is pointless and vain -for this topos and its wider resonances, see A.J. MinnIs, «Tobit's Dog and the Dangers of Literalism: William Woodford OFM as Critic of Wycliffite Exegesis», in M.F. Cusato - G. Geltner (eds.), Defenders and Critics of the Franciscan Life: Essays in Honor of John V. Fleming, Brill, Leiden 2009, pp. 41-52. EWS, vol. 1, p. 241/36-40, points out that «hit is no nede to busyen [occupy] vs to wyte [know] what hizte [is the name of] Tobies hownd».

${ }^{20}$ Sermones, vol. 1 , serm. 11, p. 73/3-11.

${ }^{21}$ On the place of lying in Wyclif's thought, and in medieval thought more generally, see D.G. Denery II, The Devil Wins: A History of Lying from the Garden of Eden to the Enlightenment, Princeton University Press, Princeton - Oxford 2015, esp. pp. 85-88, and further bibliographical references therein. 
etc. She therefore leaves everything to his will, and «implicans suam condicionalem peticionem iam cessare» («indicating that her conditional request had already lapsed»), says to the servants, «Whatsoever he shall say to you, do ye» (John 2:5 $)^{22}$.

This detailed analysis, which then segues into a critical comment on 'nostri prelati et clerici' who should not 'sophisticate' against the commands and counsels of $\mathrm{Christ}^{23}$, is both drawn on and simplified by EWS 33, in a manner that is readily comprehensible as a self-conscious attempt to address a non-specialist audience. Mary is said to have meant «on curteys maner as sche durste that Iesu schulde helpe this feeste of wyn by his miracle» («in as courteous a fashion as she was capable of that Jesus should help this feast with wine through his miracle»). Jesus's response is described as 'straunge' to indicate that he would need his godhead and not his manhood to perform miracles. The sermon, following Wyclif, next invokes Augustine as authority, and then clarifies that Mary, «supposyng ay goode of hire sone» («always supposing good of her son») asked the servants to do what Jesus said ${ }^{24}$.

Wyclif's own sermon then leads on to a logical / natural-philosophical dubium («dubitatur a naturalibus e logicis»): how is the conversion of water into wine possible? Wine and water belong to different species («corpora disparium specierum»); one must therefore be corrupted ('corrumpi') to generate another. However, the author of nature taught, via the words of this miracle, a more profound philosophy than the peripatetic sect touched upon; the truth is that «quecunque materialis essencia potest per auctorem nature fieri qualiscumque; et sic in fundamento materiali non est specierum distinccio» («any material essence can be converted into anything else by the author of nature; and thus in the material foundation or basis there is no distinction of species»). The Platonists are of this view; Aristotelians against. John (described as «profundus philosophus») is a Platonist «quia (ut refert Aug.) invenit in libris Platonis totam sentenciam decem proposicionum theologicarum, quas Johannes in principio sui evangelii inculcate [...]» («because, as Augustine says, he found in the books of Plato the entire

${ }^{22}$ Sermones, vol. 1, serm. 11,pp. 73/13-74/8; for some of the authorities, including Augustine and Hugh of St Victor, that Wyclif is drawing on here, see EWS, vol. 4, p. 268.

${ }^{23}$ Sermones, vol. 1, serm. 11, p. 74/10-13.

${ }^{24}$ EWS, vol. 1, pp. 360/9-361/22. 
substance of the ten propositions of theology which John emphasizes in the beginning of his gospel»). Wyclif then seems to suggest that the conversion of water into wine is also in accordance with the «modum loquendi Aristotelis», who states that movements may be distinguished according to the end to which they tend, i.e. the new substantial or accidental form which replaces a previous one. And since everything in the Aristotelian schema tends to its own perfection, «notatur miraculi huius perfeccio a termino ad quem, cum post aquam dicitur factum vinum» («the perfection of this miracle is to be noted from its end-point, since after it the water is said to be made into wine» $)^{25}$.

This compressed and involved philosophical discussion is one in which Wyclif draws, in a highly elliptic fashion, on his extensive, and as Zénon Kaluza and others have shown, idiosyncratic theorizations of prime matter in De materia et forma, De logica and other philosophical writings ${ }^{26}$. Wyclif then characteristically puts it to one side: «sed dimisso isto sensu philosophico attendendum est alium sensum misticum dulciorem» («but laying aside this philosophical sense, one must attend to another sweeter mystical sense» $)^{27}$.

EWS 33, perhaps understandably, rather balks at the challenges of this particular dubium! Nevertheless -and this is a defining characteristic of the discursive texture of the sermons- it cannot quite leave the matter to one side, and makes an allusive and dismissive reference to the naturalphilosophical discussion:

Pe turnyng of pis watur into good wyn techup vs how Crist maade his lawe moore sauery, as be wyn was betture pan pe watur byfore. And riht as o substaunce is furst watur and sip wyn, riht so o lawe is furst coold and sipen hoot [...] And drede we not pese philosophres

${ }^{25}$ Sermones, vol. 1 , serm. 11, pp. 75/7-76/9.

${ }^{26} \mathrm{Z}$. KALUZA, «La notion de matière et son évolution dans la doctrine wyclifienne», in Mt. Fumagalli Beonio Brocchieri - S. Simonetta (eds.), John Wyclif: Logica, politica, teologia, SISMEL - Edizioni del Galluzzo, Firenze 2003, pp. 113-151; also see J.A. Robson, Wyclif and the Oxford Schools: The Relation of the "Summa de Ente" to Scholastic Debates at Oxford in the Later Fourteenth Century, Cambridge University Press, Cambridge 1961.

${ }^{27}$ Sermones, vol. 1, serm. 11, p. 76/13-15. There are several occasions in Wyclif's sermons when the philosophical discussion is 'parked' on one side while he proceeds into homiletics or polemics: for some examples and discussion, see GHOSH, «Genre and Method», pp. 175-176. 
to graunten hem apertly pat pe same substaunce is furst water and sip wyn; ne drede we not dyuynes pat askyn in pis cas what ping was maad newe of Crist in pis myracle, sip qwalite as colowr or sauowr of wyn may not be by hitself, as Austyn seip ${ }^{28}$.

The conversion of this water into good wine teaches us how Christ made his law more full of flavour, since the wine was better than the preceding water. And just as one substance is first water and then wine, similarly is one law [i.e. the Old Law] first cold and then hot [i.e. in the New dispensation] [...] Let us not be afraid to assert openly to philosophers that it is one and the same substance which is first water and later wine; nor should we be bothered by theologians who quibbling ask, if that is the truth, what new matter was added by Christ in this miracle since qualities such as colour or taste of wine cannot exist independently, as Augustine says.

The tonality of this passage is complex. As is characteristic of this genre of vernacular Wycliffite writing, while philosophical and theological debate is dismissed as the domain of mere verbal quibbling and academic vainglory, there is an implicit assumption of an understanding of the concepts out of which such debates arise. The voice in such passages is both intra-clerical and anti-clerical; its implied audience is simultaneously the «clerks of schools» who would appreciate its mocking and dismissive inflections, and, ostensibly, «pore symple men» / «lewid men \& symple lettrid prestis» ${ }^{29}$. As if recalled to a consciousness of the latter audience, our sermon then proceeds to omit Wyclif's long polemical discussion of how the 'manifest heresy' of 'our religious' (i.e. the monastic and mendicant orders) consists in adulterating Christ's pure wine through the addition of their own traditions. Also omitted is his discussion of the different kinds of consent that we may give to -and thereby be culpable of-this adulteration of God's

${ }^{28}$ EWS, vol. 1, p. 362/52-61.

${ }^{29}$ On Wycliffite writers' predilection for postulating, even in their most learned texts, an audience of the 'simple', see C. von Nolcken, "A "Certain Sameness" and our response to it in English Wycliffite texts», in R.G. NEWHAuSER - J.A. Alford (eds.), Literature and Religion in the Later Middle Ages: Philological Studies in Honour of Siegfried Wenzel, Medieval \& Renaissance Texts \& Studies, Binghamton, NY 1995, pp. 190-208: 201. The Glossed Gospels, the product of painstaking learning and research into patristic originalia, posit as main readership one that is composed of ignorant and poor men, though, as Hudson points out, such cannot plausibly have appreciated or used their sophisticated academic learning: see Hudson, Doctors in English, p. cxxxix. 
law ${ }^{30}$. Instead, and more appropriately for a vernacular sermon, it ends with a contrast between worldly feasting, which is first full of flavour and then as wormwood, and 'goostly foode', which is first unsavoury and then sweet, like herbs and spices which need grinding to elicit their fragrance ${ }^{31}$.

The discursive density and tonal ambiguity of sermons such as this raise some important questions about readership, comprehensibility and projected use. It should be noted that Wyclif's phrase 'creditur a magis probabili' in the passage quoted above is replaced by 'as men seyn comunly' in the vernacular sermon. Indeed, a recurring thematic in EWS is 'common understanding', 'common speech', 'understanding of the people'. While apparently simple, these phrases actually reprise a range of complex and often conflicting discourses relating to scriptural language and the 'proper' language of exegesis and theology, to rhetoric and cognition, to probabilism and the authority of interpretative communities, and draw on a range of equally complex and conflicting meanings attached to the word 'common'. The resultant terrain of debate is therefore conceptually messy but polemically fertile.

We will begin to explore some of the major flashpoints in this terrain by looking in some detail at a particularly intellectually ambitious sermon. EWS Sermon 30 on the Sunday Gospels has as theme John 1 and offers a convoluted discussion of the hermeneutic and other complexities of John 1:32 ('I saw the Spirit coming down, as a dove from heaven; and he remained upon him') which deserves to be quoted at some length:

But clerkys wyten pat per ben two manerys of seyng, pat ben personel seyng and habitudynel seyng; pis dowue myste not be God in his kynde but by som habitude hit singnefiep God, and pus by auctorite of God hit is God. And zif pow seye pat eche ping by pis schulde be God, as eche Godis creature signifiep his makere [...] and pus, sip God is bytokned furste and moste in eche ping, why may men not graunte pat God is eche ping?

In pis mote men vndirstonde diuersite in wordis and to what entent pes wordes ben vndirstondene. And pus by auctorite of pe lawe of God

${ }^{30}$ Sermones, vol. 1, serm. 11, pp. 77/15-78/22. On the complexities in Wyclif's discussion of consent, see F. SOMERSET, «Before and After Wyclif: Consent to Another's Sin in Medieval Europe», in J.P. HornBECK II - M. VAN Dussen (eds.), Europe after Wyclif, Fordham University Press, New York 2017, pp. 135-172.

${ }^{31}$ EWS, vol. 1, p. 363/79-84. 
schulde men speke her wordis as Godis lawe spekip, and straunge not in speche from vndirstondyng of pe peple, and algates be war pat pe puple vndirstonde wel, and so vse comun speche in per owne persone; and, zif pei spekon in Cristes persone wordis of his lawe, loke pat pei declaren hem for drede of pryue errour. And scorne we pe argumentis pat fooles maken here pat by pe same skyle schulde we speke bus, for God spekip pus in wordus of his lawe; siche apis liknessis passen bestis foly [...] Pese wordus pat God spekip schulde we algatys graunte, and declaren hem to trewe vndyrstondyng. And recke we not of argumentis pat sophistres maken, pat we ben redarguede grauntynge pat we denyen; for we graunte be sentence and not only pe wordys [...] And pus, zif we graunten pat Crist ys alle pingus, hit sewep not hereof pat Crist is an asse, ne pat Crist is in eche ping, or what ping we wole nempnen, for God seip pe toon and he seip not pe topur. But we graunten pat Crist is bope lomb and schep, for Godis lawe grauntep bope pese two of hym; and so Crist is a lioun and a worme, and pus of many pingis pat hooli writt tellip. And hit is ynow to seye for dyuersite pat God hap special sentence of one and not so of anopur. And pus be comun vndyrstondyng schulden we algatis holde, but zif Godes wordis tauzten vs his proper sence ${ }^{32}$.

But clerks know that there are two manners of speech: these are personal speech and habitudinal speech; this dove cannot be God according to his nature, but [instead] it signifies God by some 'habitude' [i.e. 'established convention of speech'], and thus by the authority of God, it is God. And if you say that, according to this argument, everything must be God, since every creature of God signifies its maker [...] and thus, since God is betokened first and foremost in everything, why might men not admit that God is everything?

In this [matter], men must understand 'diversity' in words and the intention according to which these words are to be understood. And thus by the authority of God's law, men should speak words as God's law does, and not remove themselves from the understanding of the people through their speech, and always take care that the people understand well, and therefore they should use common speech when speaking in their own voice; furthermore, when they speak in Christ's voice the words of his law [i.e. when they are quoting Christ], they should make sure that they clarify these words in order

${ }^{32}$ EWS, vol. 1, pp. 347/50-348/93. This sermon is also edited in A. Hudson (ed.), Selections from English Wycliffite Writings, Cambridge University Press, Cambridge 1978, pp. 113-115. 
to avoid unforeseen error. And here we reject the argument that fools make that by the same reasoning we should speak as God speaks in his law; such idiotic analogies surpass the stupidity of beasts [...] These words that God speaks we should always accept and expound according to the correct understanding. And let us not take heed of the argument of sophists that we are confuted in granting what in fact, we deny; for we grant the sense and not only the words [...] And thus, if we grant that Christ is all things, it does not follow from this that Christ is an ass, or that he is in everything, or in whatever thing we choose to name, for God says one thing and not the other [i.e. the Bible uses some creatures to speak of God and not others]. But we grant that Christ is both lamb and sheep, for God's law [i.e. the Bible] speaks of him in terms of these two creatures; and in a similar way, Christ is a lion and a worm, and various other things that Holy Writ mentions. And it is enough to say that, because of 'diversity' ${ }^{33}$, God attaches a special meaning to one [creature] and not to another. And thus we should always abide by the common understanding [when expounding scriptural words] unless God's words teach us his own [intended] sense ${ }^{34}$.

As Anne Hudson explains in her notes to this passage, the author here attempts to explicate how John's words should be understood since the question arises as to the precise manner in which the Holy Spirit may have been said to «come down from heaven as a dove». The sermon-writer makes a distinction between 'personal' and 'habitudinal' saying, the latter implying that by a conventional manner of speech, it is indicated that the Holy Spirit, in Hudson's words, «inhered in the dove as a transitory theophany not as an incarnation». This then leads the homilist to discuss -and this will form the focus of my analysis- which kinds of language one should use when explicating scripture to the 'people'. It is asserted that except when rehearsing the words of scripture, the exegete or homilist must use 'common speech'. In other words, it is legitimate to diverge from conventional linguistic modes of signification only when scripture authorizes us to do so by using language in an 'improper' way -as for instance when God is described as a lamb or a sheep or a lion or a worm-

33 'Diuersite' here has the sense of 'distinctness and individuality': $M E D$, s.v. 2(a).

${ }^{34}$ I have relied on Hudson's extensive annotations and both drawn on and, on occasion, diverged from her suggested readings: see HuDSon (ed.), Selections, pp. 193194; EWS, vol. 4, pp. 258-263. 
and when we are quoting that scripture ${ }^{35}$. Our sermon half-acknowledges that there can be an opposing view: if one is to expound and explicate the Bible to the people in the 'language of the people', would one not be going against the divine intentions encoded in the obscurities, figurations and obliquenesses of the often parabolic and 'dark' scriptural discourse? This was a particular problem for the Wycliffite sermons as Wyclif himself repeatedly stressed the absolute uniqueness of scriptural language and the absolute obligation it places upon us to abide by its special form, though, as Hudson points out, Wyclif's emphasis on scripture as a model for all human speech has the Augustinian proviso that human speech can at best be merely a poor imitation of that of $\operatorname{God}^{36}$.

Underlying this emphasis on 'common speech' is an opposition -often made explicit in Wycliffite writing- between common speech and understanding and the discourse of scholastic experts, generally referred to by a derogatory use of "sophistry' ${ }^{37}$. This is at first glance simpler. The technical discourses of philosophy and theology can be dismissed easily enough as 'sophistic', 'curious' and concupiscent, and Wyclif's writings constitute an often highly coloured, if imprecise, litany of such accusations directed against unspecified adversaries (the moderni). But these discourses could, and were, defended by many scholastic thinkers as having a special access to the specific difficulties and mysteries of scripture. As Catherine König-Pralong has pointed out in her work on the magisterium of the medieval university, «la verité est unique et elle n'est souvent pas accessible au sens commun, c'est-a-dire au commun des mortels». What

${ }^{35}$ The question of the 'improperness' or metaphoricity of scriptural locutions constituted an abiding and fraught nexus in Wycliffite discourse, as, among other things, it had problematic implications for the literal versus figurative understanding of Christ's Eucharistic formulation; indeed, this sermon itself broaches that controversial topic in a characteristically compressed and allusive manner (EWS, vol. 1, pp. 346/37347/50): for a full elucidation of the passage, see Hudson's analysis (n. 33 above).

${ }^{36}$ Wyclif declared in De veritate sacrae Scripturae that «cristianus debet loqui sub authoritate scripture verba scripture secundum formam, qua scriptura ipsa explicat»; cf. De veritate sacrae Scripturae, Ed. by R. Buddensieg, 3 vols., Trübner \& Co., London 1905-1907, vol. 1, pp. 51/26-52/1. See K. GHosh, The Wycliffite Heresy: Authority and the Interpretation of Texts, Cambridge University Press, Cambridge 2001, p. 48.

${ }^{37} \mathrm{On}$ the polemical usage of 'sophistry' and related words in Wycliffite discourse, see R. Copeland, «Sophistic, spectrality, iconoclasm», in J. Dimmick - J. Simpson N. Zeeman (eds.), Images, Idolatry and Iconoclasm in Late Medieval England: Textuality and the Visual Image, Oxford University Press, Oxford 2002, pp. 112-130. 
she calls «une orthodoxie de l'invraisemblable» is therefore posited by the magisterium as a defence of the specialist and exclusive access that 'expert' scholastic discourses have to a higher order of theological reality ${ }^{38}$. In the contemporary English context, for example, such a defence constitutes one of the over-arching themes of the early-fifteenth-century set of macaronic anti-Lollard sermons of Oxford Benedictine provenance ${ }^{39}$ which insist pervasively, and with much colourful polemic, that high theology is the exclusive province of university-trained theologians and emphatically not that of the «communis populus [who] pro maiori parte est illiteratus» («the common people who for the greater part are illiterate» $)^{40}$. Richard Ullerston, an Oxford theologian and contemporary opponent of Wycliffism, has as a basic assumption, throughout his otherwise notably open-minded 1401 determinatio on the legitimacy or otherwise of biblical translation, that there is an unbridgeable gulf between learned and lay discourses, between technical academic theology and instruction in biblical teachings: indeed, drawing on Genesis 11:6 («And he [i.e. the Lord] said, Behold, it is one people, and all have one tongue [...]»), he posits that an identity of learned and lay language obtained so very long ago that it virtually recedes into the mythic -i.e. before Babel! ${ }^{41}$

${ }^{38}$ C. KÖNIG-PRALONG, «L'empire de la doctrine: Théologie versus sens commun», in J.-Ph. Genet (ed.), La vérité. Vérité et crédibilité: construire la vérité dans le système de communication de l'Occident (XIII ${ }^{e}$-XVII ${ }^{e}$ siècle): Actes de la conférence organisée à Rome en 2012 par SAS en collaboration avec l'École française de Rome, Publications de la Sorbonne - École française de Rome, Paris 2015, pp. 95-113: 98. See also the suggestive studies of the concept and status of 'experts' (experti / periti) in later medieval Europe: F. Rexroth, Expertenweisheit: Die Kritik an den Studierten und die Utopie einer geheilten Gesellschaft im späten Mittelalter, Schwabe, Basel 2008; ID., «Systemvertrauen und Expertenskepsis. Die Utopie vom maßgeschneiderten Wissen in den Kulturen des 12. bis 16. Jahrhunderts», in B. Reich - F. ReXroth M. Roick (eds.), Wissen, maßgeschneidert: Experten und Expertenkulturen im Europa der Vormoderne, Oldenbourg, München 2012, pp. 12-44.

${ }^{39}$ Collected together in MS. Oxford, Bodleian Library, Bodley 649; see A Macaronic Sermon Collection from Late Medieval England: Oxford MS Bodley 649, Ed. and transl. by P.J. Horner, Pontifical Institute of Medieval Studies, Toronto 2006.

${ }^{40}$ For this reference and discussion, see K. Ghosh, «Magisterial Authority, Heresy and Lay Questioning in Early Fifteenth-Century Oxford», Revue de l'histoire des religions, 231 (2014) 293-311: 299.

${ }^{41}$ «[...] usque ad construccionem turris Babel post diluuium erat eadem lingwa clericis et uulgaribus dicit enim scriptura Genesis $\mathrm{xj}$ »: MS. Wien, Österreichische Nationalbibliothek, 4133, f. 197vb (henceforth ÖNB 4133). For discussions of 
This opposition between 'common sense' and academic theological discourse was further complicated by the fact that 'common understanding' was also widely used to mean scholarly consensus about the meaning of technical terms and the interpretation of ambiguous statements. Indeed, the diffuse semantic range of the word 'common' is a major complicating ambiguity in these polemical oppositions. As Andrea Robiglio has clarified, 'common' can have quite contradictory referents. 'Common understanding', as I just pointed out, can refer to a shared expert consensus. In this sense, contemporary scholastic theologians can be held to abide by a 'common doctrine' which goes back to Christ and the apostles as the 'doctores communes' -hence the praise devoted to Aquinas as offering 'communis illuminatio / ordo/ doctrina'42. This is the «fidei series» («continuity of faith») often resorted to by late-medieval anti-Wycliffite polemicists such as Thomas Netter to justify and defend their own attempts at synthesizing a common theological position as distinct from what they viewed as perverse heretical singularity and falsity ${ }^{43}$. The authority of

Ullerston's determinatio, see A. HuDson, «The Debate on Bible Translation, Oxford 1401», in Ead., Lollards and their Books, Hambledon Press, London 1985, pp. 6784; GHosh, The Wycliffite Heresy, pp. 86-111; F. SOMERSET, «Professionalizing Translation at the Turn of the Fifteenth Century: Ullerston's Determinacio, Arundel's Constitutiones», in F. SOMERSET - N. WATSON (eds.), The Vulgar Tongue: Medieval and Postmedieval Vernacularity, Penn State University Press, University Park, PA 2003, pp. 145-157. I am much indebted to Anne Hudson and Elizabeth Solopova for allowing me to consult their corrected transcription of the manuscript.

${ }^{42}$ A.A. Robiglio, «Christ as Common Doctor and John Duns Scotus's Place in the History of Hermeneutics», in P. BÜtTGen - R. IMBACH - U.J. SCHNEIDER H.J. SelDERHUIs (eds.), Vera Doctrina:Zur Begriffsgeschichte der Lehre von Augustinus bis Descartes, Harrassowitz, Wiesbaden 2009, pp. 85-113.

${ }^{43}$ On Netter's vast anti-Wycliffite compendium, the Doctrinale antiquitatum fidei ecclesiae catholicae, see GHosh, The Wycliffite Heresy, pp. 174-208: 194; M. Bose, «The Opponents of John Wyclif», in I.C. Levy (ed.), A Companion to John Wyclif: Late Medieval Theologian, Brill, Leiden 2006, pp. 407-455: 436-446; J. BERGSTRÖMAllen - R. Copsey (eds.), Thomas Netter of Walden: Carmelite, Diplomat and Theologian (c. 1372-1430), Edizioni Carmelitane, Roma 2009; K.J. Alban, The Teaching and Impact of the Doctrinale of Thomas Netter of Walden (c. 1374-1430), Brepols, Turnhout 2010; I.C. Levy, Holy Scripture and the Quest for Authority at the End of the Middle Ages, University of Notre Dame Press, Notre Dame 2012, pp. 117-149. For an example of the widespread allegation that Lollards held on to their own perverse readings of the Bible as opposed to 'common' ones, see the Register of Nicholas Bubwith, Bishop of Bath and Wells (1407-24), «Lollardi [...] verum 
'common understanding' was also fundamental to hermeneutic discussions in legal theory and practice ${ }^{44}$.

'Common' could also, of course, refer to the common-sensical, the basic, the simple, the non-technical or -scholastic ${ }^{45}$, which could, in a further complication, be aligned with biblical language itself, above all with the language of Christ and the apostles. For example, Jean Gerson, writing in the early fifteenth century, repeatedly emphasized that the province of the instruction of the people in faith and morals was that of 'moral logic' -and for this what was required was a rhetoric which drew on common linguistic usage, the «vulgaris usitata locutio», «communes hominum locutiones», the «modus loquendi communis» which is also, significantly, the «modus loquendi evangelicus». Such ought to be the proper language of theology, the «stylus theologicus humilis et simplex» as opposed to scholastic subtleties and sophistries as well as platonic obscurities (of which he accused the Wycliffites and Hussites $)^{46}$. Gerson's polemical vision

scripture sacre intellectum ad usum privatum non communem [...] pervertentes», cited by A. Russell, Conciliarism and Heresy in Fifteenth-Century England: Collective Authority in the Age of the General Councils, Cambridge University Press, Cambridge 2017 , p. 178. On some of the local problems that could be faced by the ecclesiastical authorities in attempting to forge a common religio-political position, see I. FORREST, «The Dangers of Diversity: Heresy and Authority in the 1405 Case of John Edward», Studies in Church History, 43 (2007) 230-240.

${ }^{44}$ See I. Maclean, Interpretation and Meaning in the Renaissance: The Case of Law, Cambridge University Press, Cambridge 1992; also see Russell, Conciliarism and Heresy, pp. 171-176.

${ }^{45}$ In the English context, there was furthermore a complex and much-debated socio-political dimension to the word 'commons', for which see the following papers by J. Watts, «Public or Plebs: The Changing Meaning of "The Commons", 13811549», in H. Pryce - J. W ATts (eds.), Power and Identity in the Middle Ages: Essays in Memory of Rees Davies, Oxford University Press, Oxford 2007, pp. 242-260; J. WatTs, «The Commons in Medieval England», in J-Ph. Genet (ed.), La legitimité implicite: Actes des conférences organisées à Rome en 2010 et en 2011 par SAS en collaboration avec l'École française de Rome, 2 vols., Publications de la Sorbonne École française de Rome, Paris 2015, vol. 2, pp. 207-222.

${ }^{46}$ On this topic, see the following essays by I. IRIBARREN, «Le Paradis retrouvé: l'utopie linguistique de Jean Gerson», Revue de l'histoire des religions, 231 (2014) 223-251; EAD., «Le théologien: poète de la doctrine. Quelques réflexions autour de la Josephina de Jean Gerson», Revue des sciences religieuses, 85 (2011) 353370; EAD., «Question de style. Langage et méthode comme enjeux rhétoriques dans l'œuvre de Gerson», in ZAHND (ed.), Language and method, op. cit., pp. 183-221; also 
of a simple pellucid imagistic language of a reformed theology aligned with a rhetorically efficacious instruction in morality and spirituality (primarily via the affect) is based on an ideological rejection of what he saw as contemporary academic theology's vainglorious and concupiscent excesses, in particular those he identified with English theology, the theologia anglicana ${ }^{47}$. Richard Ullerston, as we have seen, had a rather different assumption about the relationship of theology to basic scriptural instruction. In the course of his defence of biblical translation, Ullerston asserts that translating the simple stories of the Bible and the life of Christ is a far cry from meddling in the mysteries of philosophical theology. The former is possible and indeed necessary (with some appropriate safeguards against lay misinterpretation) while the latter -especially topics such as devotions and the religious orders, divine attributes and divine ideas, the relationship of human nature to the Word, accidents without a subject and numberless others- should not be approached, even by those who have prepared themselves through profound and assiduous study and labour, without fear and trembling ${ }^{48}$.

Lying behind the Wycliffite sermon's ambiguous engagement with the notion of commonality is that vast hinterland of scholastic discussion relating to the «medium and message», to borrow Alastair Minnis's phrase, of both scriptural and theological (here inclusive of exegetical) discourse. As Minnis has pointed out in relation to Henry of Ghent's theorizations:

Z. Kaluza, «La Doctrine selon Jean Gerson», in Büttgen - IMBaCh - SChNeIDER Selderhuis (eds.), Vera Doctrina, op. cit., pp. 115-140: 132; M.J.F.M. Hoenen, "'Modus loquendi platonicorum". Johannes Gerson und seine Kritik an Platon und den Platonisten», in S. Gersh - M.J.F.M. HoEnen (eds.), The Platonic Tradition in the Middle Ages: A Doxographic Approach, De Gruyter, Berlin 2002, pp. 325-343; A. RoBerT, «L'idée de logique morale aux XIII et XIVe siècles», Médiévales, 63 (2012) 27-46.

${ }^{47}$ For background and full discussion, see Z. KALUZA, Les querelles doctrinales à Paris. Nominalistes et réalistes aux confins de XIVeet XVe siècles, Lubrina, Bergamo 1988.

${ }^{48} \ll[\ldots]$ eximie scripturarum difficultates non debent plebi propalari. Istud potest sane concedi et specialiter de illis ad que non sunt abiles, puta deuocionibus et religionibus, in diuinis de attributis et ydeis, de relacione nature humane ad uerbum, de accidentibus sine subiecto infinitisque alijs, ad que ex longinquo tempore philosophia politi cum graui studio et laboris uehemencia vix sufficiunt palpitando attingere. Sed ex isto non conuenienter concluditur, quod plane scripture historie, uita Christi, eius miracula et doctrina non possunt plebi enarrari in uulgari sicut iacent [...]» (ÖNB 4133, f. 204vb). 
Scriptural exposition should, he declares, always be prepared with one's specific audience in mind, and since many learners are coarse (grossus) and stupid, in their case a broad (grossus) and common exposition is, in the main, to be provided [...] A particular exposition should not be propounded to someone whose abilities are inadequate to cope with it [...] The modus of holy scripture is singular but the needs of human beings are diverse -and hence stylistic diversity and pluralism in the Bible, and exegetical diversity and pluralism on the part of Bible commentators, is fully justified ${ }^{49}$.

Richard Ullerston, for instance, devotes a long section to a discussion of the different modes in which scripture signifies truth to listeners and readers of different intellectual and spiritual capacities. Jerome, says Ullerston, comments on Psalm 86:6 that scripture must be made available to all, unlike the hermetic and obscure writings of Plato:

«[...] Plato scripsit in scriptura; sed non scripsit populis, sed paucis. Uix enim intelligunt tres homines. Isti vero, hoc est, principes ecclesie et principes Christi non scripserunt paucis sed vniverso populo». Hec Ieronimus ibidem. Quamuis igitur ewangelium ut refertur sit omnibus populis promulgandum, differenter tamen, istis grossius et sensibilius; illis uero subtilius et eminencius ${ }^{50}$.

«Plato wrote his scripture, but not for the [many] people but for the few, for scarcely three people understand [it]. But they, i.e. the elders of the Church and the elders of Christ, wrote not for the few but for all people». Thus Jerome. Therefore, although as he says the gospel is to be promulgated/ published to all people, nevertheless [this must be done] in a differentiated manner, more roughly and perceptibly [i.e. via the corporeal senses] for some, with more subtlety and distinction for others.

${ }^{49}$ A.J. MinnIs, «The Accessus Extended: Henry of Ghent on the Transmission and Reception of Theology», in M.D. JoRDAN - K. EMERY (eds.), Ad litteram: Authoritative Texts and their Medieval Readers, University of Notre Dame Press, Notre Dame 1992, pp. 275-326: 287-88; also see ID., «Quadruplex Sensus, multiplex modus: scriptural sense and mode in medieval scholastic exegesis», in J. WhITMAN (ed.), Interpretation and Allegory: Antiquity to the Modern Period, Brill, Leiden 2000, pp. 231-256; ID., «Medium and Message: Henry of Ghent on Scriptural Style», in Newhauser - Alford (eds.), Literature and Religion, op. cit., pp. 209-235.

${ }^{50}$ ÖNB 4133, f. 206ra; the Jerome reference is to his commentary on Psalm 86 in Breviarium in psalmos, PL 26, col. 1084A. 
And as Minnis points out, Moses himself was held, in Nicholas of Lyra's vastly influential biblical commentary, to be «a man concerned with the needs and capacities of his audience». ${ }^{51}$

The Wycliffite position as expressed in EWS 30, however, is fundamentally opposed to the hierarchical ${ }^{52}$ and rhetorical $^{53}$ vision and values implicit in Henry's and Ullerston's theorizations. The Wycliffite author's point is not that theological discourse should be tailored to audience, but that such discourse must always abide by the 'common' senses of words except in the few cases where it must not -i.e. when scripture uses words in a figurative or parabolic sense and when these words must be rehearsed. The theologian must not seek to emulate the figurative mode of scripture and recklessly extend it to contexts where it is not appropriate or 'habitudynel', i.e. endorsed by the divine intention encoded in a (scriptural) convention.

While the Wycliffite sermon thus invokes the notion of 'common speech' as the norm, it is to be noted that all this discussion in favour of 'common speech' is nevertheless informed by a fairly specialized and technical understanding of Sprachphilosophie as mediated by Wyclif ${ }^{54}$. It

${ }^{51}$ MinNIs, «Quadruplex Sensus», p. 252.

${ }^{52}$ Of relevance here is von Nolcken's discussion of Wycliffite attempts, linguistic and otherwise, to establish what she calls 'group solidarity': «They wanted to demonstrate [...] that where they really belonged was with the group of those resolving themselves towards the One'. She quotes EWS, vol. 1, p. 483/69-75: «And so onheed of moup [a unity of voice] shulde make accord in holy chyrche; but now dyuersite of mowpus makip discord among men»: «A “Certain Sameness"», pp. 206-207. See also Fiona Somerset's discussion of what she calls 'a lollard community united by love and governed by God's law': Feeling like Saints: Lollard Writings after Wyclif, Cornell University Press, Ithaca - London 2014, esp. chapter 2 (p. 73).

${ }^{53}$ Note that Wyclif himself in effect replaces rhetoric with what he calls 'logic' in his reading of Augustine (and of scripture): see GHosh, Wycliffite Heresy, pp. 46-52; ID., «Logic and Lollardy», Medium Aevum, 76 (2007) 251-267; A. Brungs - F. GoubIER, «On Biblical Logicism: Wyclif, virtus sermonis and Equivocation», Recherches de théologie et philosophie médiévales, 76 (2009) 199-244; F. GoubIER, «Wyclif and the logica Augustini», Medioevo, 36 (2011) 137-164.

${ }^{54}$ For details of the sermon's reliance on a range of Wyclif's writings, see Hudson's annotations: see above n. 34. Indeed, Thomas Netter thought that this sermon was by Wyclif himself and conflated some of its Sprachphilosophie with related passages from Wyclif's Latin works when refuting it. For details of Netter's citations, eight in all, of the English Wycliffite sermons in Latin translation, and their implicit or explicit ascription to Wyclif, see EWS, vol. 4, pp. 22-24. 
also appears to assume at least a good working-knowledge of the methods and vocabulary accompanying such philosophy in the presumed audience of the sermons. Again, a passage from Richard Ullerston is illuminating in this context. When defending biblical translation, he points out that the argument (derived from Roger Bacon) that translating logical texts into the vernacular would necessitate the invention of a new vocabulary is indeed correct, and that this new vocabulary, though it would be comprehensible to those who already knew logic in the original language (pace Bacon), would not be understood by 'common people'. However, Ullerston goes on to say, the Bible is a different matter as its moral teachings would be entirely intelligible:

Ad illud autem quod addit Bacon in argumento suo quod oporteret uolentem conuertere logicam in linguam maternam noua uocabula fingere, conceditur illud [...] Et quando ulterius additur quod talis sic loquens solum intelligeretur a seipso, dicitur quod hoc non sequitur, intelligeretur enim ab illis qui scirent logicam in priori lingua sicut iste. Sicut modo quando in uulgari loquimur de consequenciis, obligacionibus et insolubilibus et huiusmodi corrumpendo vocabula quedam Latina de facili intelligeretur vt predixi. Non tamen a populo simpliciter rusticano nisi per magnam asuefaccionem. [Sed] de translacione scienciarum liberalium modo non loquimur, sed ewangelii populo predicandi ${ }^{55}$.

Regarding Bacon's addition to his argument that it would be necessary for anyone wishing to put logic into [his] mother-tongue to invent a new vocabulary, it is conceded [...] And when he further adds that anyone speaking thus would be understood only by himself, I say that this does not follow, for he would be understood by those who knew logic in the original language, like himself. For instance, when these days we speak in the vulgar tongue of consequences, obligations, insolubles and suchlike, altering some Latin terms, we are understood easily as I have said before. Nevertheless, this would not be straightforwardly possible for country-people without long habituation. [But] we are not talking about the translation of the liberal arts now, but of the gospel that is to be preached to the people.

Ullerston's discussion helps us see very clearly what is most idiosyncratic about the English sermons: their pervasive reliance on

${ }^{55}$ ÖNB 4133, ff. 201vb-202ra. 
rendering into the vernacular a technical or quasi-technical vocabulary without sign-posting or any other pedagogic assistance.

The cumulative impact of such a homiletic style in the English Wycliffite sermons is therefore difficult to assess. The oblique and compressed use of Wyclif's Latin sermons, themselves compressed, idiosyncratic and allusive, is on occasion such that the resulting texture verges on the opaque. As Hudson says:

It is $[\ldots]$ characteristic of these sermons, whether in the polemical or exegetical field, that a brevity of allusion amounting at times to apparent précis of argument is coupled to a tendency to slide sideways, unpredictably moving from one topic to another without any clear signposting. Whether this reflects an authorial quirk of mind or anticipated audience comprehension of a subject from the slightest of hints, or both, this habit poses very considerable problems for the modern interpreter ${ }^{56}$.

It might be pointed out that such a style -as developed by Wyclif-also posed considerable problems for contemporaries such as John Kenningham, who frequently commented unfavourably on the difficulty of his thought and its idiosyncratic expression ${ }^{57}$. When 'translated' into English, the difficulties multiply, for such a discourse in effect constitutes a rhetoricopolemical appropriation and rewriting -almost a 'scrambling'- of the axioms, premises and fundamental methodological assumptions that made scholastic theological enquiry intelligible. The style and modus procedendi of Wyclif's voluminous later productions amount to nothing less than an implosion of scholastic method from within; and this translatio of that style and mode, ostensibly for the benefit of the 'people', re-enacts that implosion in alternating accents of serious, if tortuous, engagement with scholastic theology and Sprachphilosophie, and their derisive and indignant dismissal. We can see why the implications of such vernacular translation for later medieval English religious, intellectual and institutional life 'after Wyclif' continued to be so very troublesome.

${ }^{56}$ EWS, vol. 4, p. 2.

57 See M.J.F.M. Hoenen, «Theology and Metaphysics. The Debate between John Wyclif and John Kenningham on the Principles of Reading the Scriptures», in Fumagalli Beonio Brocchieri - Simonetta (eds.), John Wyclif, op. cit., pp. 23-55; and K. GHosh, «Genre and Method», pp. 179-182. 